\title{
Investigating the effects of intellectual capital on organizational performance measurement through organizational learning capabilities
}

\author{
Hasan Darvish $^{\mathrm{a}}$, Ali Akbar Ahmadi ${ }^{\mathrm{a}}$, Ali Reza Kafashzadeh ${ }^{\text {, }}$, Samira Farid ${ }^{\mathrm{b}}$, and Nabi ollah \\ Nejatizadeh $^{\mathrm{c}}$
}

${ }^{a}$ Department of Economy, Management and Accounting, Payame Noor University, PO BOX 19395 - 3697,Tehran, Iran

${ }^{b}$ Department of Public Administration, Payame Noor University, PO BOX 19395 - 3697, Tehran, Iran

${ }^{c}$ Department of business management, Payame Noor University, PO BOX 19395 - 3697, Tehran, Iran

\section{H R O N I C L E \\ A B S T R A C T}

\section{Article history:}

Received July 2, 2012

Received in revised format

28 October 2012

Accepted 11 November 2012

Available online

November 122012

Keywords:

Human capital

Structural capital

Relational capital

Organizational performance

Organizational learning

\begin{abstract}
During the past few years, there have been growing interests on intellectual capital due to industrial changes on the market. Thus, identifying different ways to create, manage, and evaluate the impact of intellectual capital has remained an open area of research. One of the most important organizational capabilities, which could help organizations create and share knowledge is to effectively use knowledge to create competitive advantage. The primary objective of this study is to investigate the effects of intellectual capital on other components and their impacts on organizational learning capability. The statistical population includes 500 employees of an Iranian organization. The study uses a sample size including 273 people using Morgan statistical table and Cronbach's alpha is calculated as 0.838 . The results of this survey indicate that human capital, relational capital and learning capabilities have positive impact on organizational performance. In addition, relational capital positively impacts learning capability and human capital influences positively on relational capital.
\end{abstract}

C) 2013 Growing Science Ltd. All rights reserved.

\section{Introduction}

One of the challenges in contemporary area of management and organizational behavior is to generate and strengthen organizational learning. Organizational learning could be gained through human capital or structural and helps people build better relationships and cooperation. According to Moullin (2002), capital is an important source, which influences certain areas and allows the individuals to get certain benefits through participation. Veismoradi et al. (2012), for instance, reviewed the relationship of social capital and the learning organizational in one of Iranian organizations. They reported that social capital had a meaningful relationship with learning organizational. Ali et al. (2012) investigated the relationship between knowledge management

*Corresponding author.

E-mail addresses: kafashzadehalireza@gmail.com (A. Kafashzadeh) 
practices and the organizational performance of Pakistan's telecommunication. The study collected necessary data from two hundred and ten (out of three hundred questionnaires) middle level managers of various telecommunications located in Rawalpindi \& Islamabad cities of Pakistan. A self designed questionnaire was implemented for data collection and the data was analyzed using the techniques of multiple regression analysis. They reported that knowledge management practices had positive and significant effect on organizational performance, which reflected that organizations that prefer knowledge management practices got beneficial outcomes than their competitors did.

Saeidipour et al. (2012) studied the impact of "emotional intelligence" on "organizational learning" among employees in an Iranian organization. They used Wesinger Emotional Intelligence Questionnaire and organizational learning questionnaire to collect the necessary data. They reported that emotional intelligence had a significant influence on organizational learning. Hsu and Fang (2009) performed an investigation on intellectual capital and new product development performance by studying on the mediating role of organizational learning capability. Riahi-Belkaoui (2003) studied intellectual capital and firm performance of some US multinational firms.

Sonnier et al. (2007) studied the Relationship between profitability and disclosure to investigate the effect of intellectual capital. Organizational learning is believed as an important source of contributing to firms' intangible assets. Organizational learning is established when each member understands the difference between optimal and present results and attempts to resolve problems. Therefore, conventional techniques and scientific management cannot take advantage of the capabilities of staff. Effective implementation of staff is necessary and organizational leadership requires reaching the necessary skills.

Valaski et al. (2012) performed an investigation on how ontologies were being implemented in the organizational learning process by investigating studies from the year of 2005 . They identified 353 papers from 11 various databases. After applying the exclusion criteria, the set was limited to 11 works, which clearly fitted to the criteria defined for review process. They classified them based on the structure and level of the ontologies.

Yu Yuan Hung et al. (2010) utilized a survey data from a Taiwan high-tech industry to introduce an integrative model of dynamic capability. They explained that although organizational learning culture substantially affected performance, its impact was mediated by dynamic capability. They also provided some supporting evidence for the hypothesis that process alignment impacts performance either directly or indirectly through dynamic capabilities.

\section{The proposed study}

The main hypothesis of this survey is as follows,

Hypothesis 1: Three components of intellectual capital including human capital, structural capital and relational capital influence on each other.

The first hypothesis consists of three sub-hypothesis as follows,

1. Human capital influences positively on structural capital.

2. Human capital influences positively on relational capital.

3. Relational capital influences positively on structural capital.

Hypothesis 2: Three components of intellectual capital including human capital, structural capital and relational capital influence learning capabilities. The second hypothesis consists of three sub-hypothesis as follows, 
1. Human capital influences positively on learning capabilities.

2. Structural capital influences positively on learning capabilities.

3. Relational capital influences positively on learning capabilities.

Hypothesis 3: Three components of intellectual capital including human capital, structural capital and relational capital influence organizational capabilities. The third hypothesis consists of three sub-hypothesis as follows,

1. Human capital influences positively on organizational capabilities.

2. Structural capital influences positively on organizational capabilities.

3. Relational capital influences positively on organizational capabilities.

Fig. 1 shows details of our proposed study.

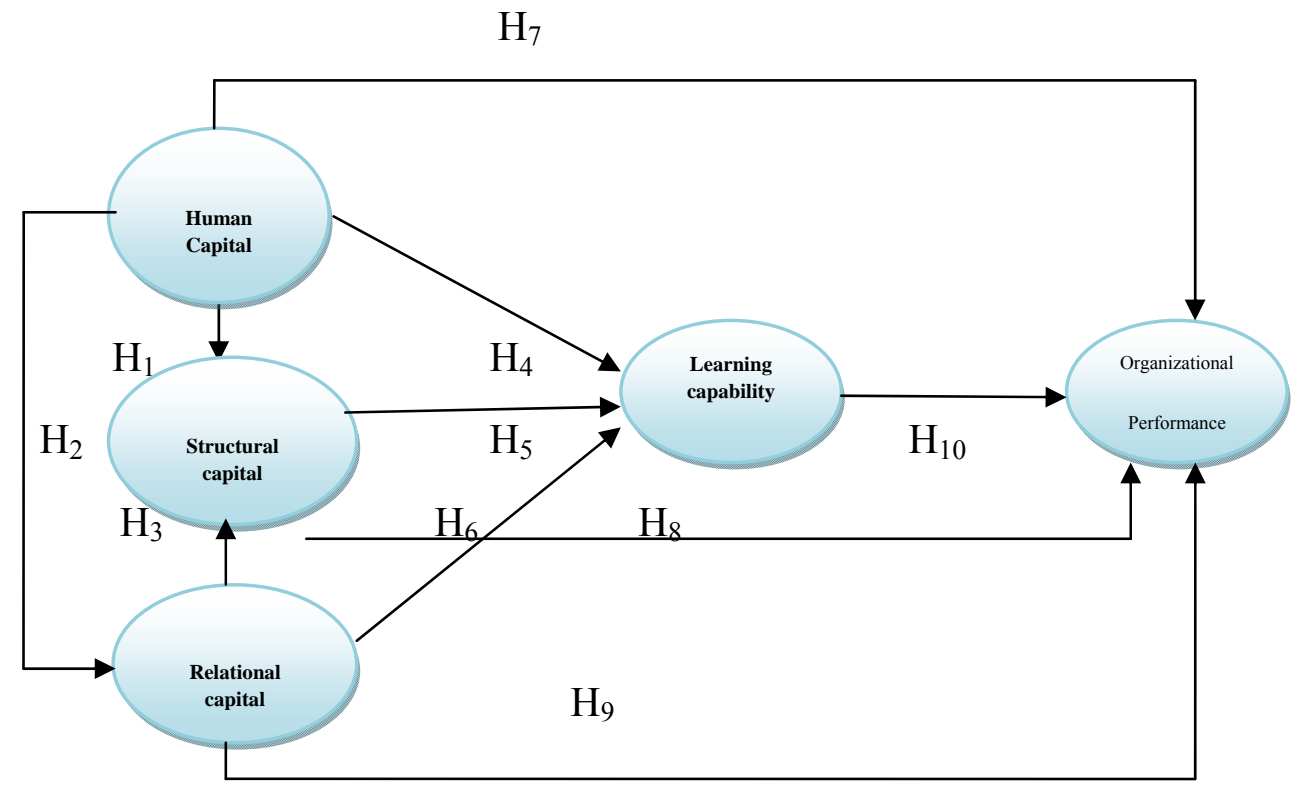

Fig. 1. The framework of the proposed study

The proposed study of this paper uses the following formula to calculate the minimum number of sample size,

$n=\frac{N \times z_{\alpha / 2}^{2} \times p \times q}{\varepsilon^{2} \times(N-1)+z_{\alpha / 2}^{2} \times p \times q}$,

where $N$ is the population size, $p=1-q$ represents the yes/no categories, $z_{\alpha / 2}$ is CDF of normal distribution and finally $\varepsilon=0.04$ is the error term. Since we have $p=0.5, z_{\alpha / 2}=1.96$ and $N=500$, the number of sample size is calculated as $n=273$. The proposed study of this paper designed a questionnaire based on the existing literature (Bontis et al., 1999; Bontis et al., 2000; Bontis \& Serenko, 2009; Brooking, 1996). Cronbach alpha (Cronbach, 1951) is calculated as 0.898, which is well above the minimum acceptable level. 
In terms of gender, $94.6 \%$ of the participants were male and only $5.4 \%$ of them were female. Most of them were middle age people and $82.78 \%$ of them maintained bachelor degree of science, $13.55 \%$ of them had master or higher degrees and only $3.66 \%$ of them maintained 2-year college degree.

Table 1 shows details of Pearson correlation test on five components of the survey.

\section{Table 1}

The results of Pearson correlation test

\begin{tabular}{llllllll}
\hline Variable & Mean & Std. Dev. & (1) & (2) & (3) & (4) & (5) \\
\hline 1.Organizational performance (1) & 4.537 & 0.652 & 1 & & & & \\
2.Learning capabilities (2) & 4.451 & 0.574 & $0.418^{* *}$ & 1 & & & \\
3.Human capital (3) & 4.812 & 0.614 & $0.236^{* *}$ & $0.135^{*}$ & 1 & & \\
4.Structural capital (4) & 4.495 & 0.805 & 0.084 & 0.036 & 0.07 & 1 & \\
5.Relational capital (5) & 4.601 & 0.605 & $0.575^{* *}$ & $0.540^{*}$ & $0.133^{*}$ & 0.033 & 1 \\
\hline
\end{tabular}

**Significance level $=0.01, *$ Significance level $=0.05$

As we can observe from the results of Table 1, there are positive correlations between learning capabilities, human capital, relational capital from one side and organizational performance from the other side when the level of significance is one percent. In addition, there are some positive correlations between learning capabilities with human and relational capital when the level of significance is five percent. Finally, we observe a positive correlation between relational capability and human capital when the level of significance is five percent.

\section{The results}

In this section, we use regression analysis to study the effects of different variables on organizational performance. The first regression model is as follows,

$$
O P=\beta_{0}+\beta_{1} H C+\beta_{2} S C+\beta_{3} R C+\beta_{4} L C+\varepsilon_{i},
$$

where $O P$ represents organizational performance, $H C$ is human capital, $S C$ is structural capital, $R C$ is the relational capital and $L C$ is the learning capability. In addition, $\beta_{i}, i=0, \cdots, 4$ are the coefficients of the regression analysis and $\varepsilon_{i}$ is the residual of the regression estimation. Table 2 shows details of implementation of ordinary least square technique.

\section{Table 2}

The results of regression analysis between organizational performance and independent variables

\begin{tabular}{lllll}
\hline \multicolumn{4}{c}{ Regression estimation } \\
\hline Variable & Non-standard & Standard & t-student & P-value \\
\hline Constant & 0.494 & & 1.296 & 0.192 \\
Human capital & 0.159 & 0.149 & 3.046 & 0.003 \\
Structural capital & 0.043 & 0.053 & 1.091 & 0.276 \\
Relational capital & 0.516 & 0.479 & 8.308 & 0.000 \\
Learning capability & 0.157 & 0.138 & 3.392 & 0.017 \\
\hline
\end{tabular}

As we can observe from the results of Table 2, human capital maintains a positive impact on organizational performance when the level of significance is one percent and when there is one unit increase in human capital, organizational performance is expected to increase by 0.159 . Relational capital also maintains a meaningful impact on organizational performance when the level of significance is one percent and we can expect that as the relational capital increases by one unit, we could expect an increase of 0.516 on organizational performance. Finally, learning capability 
influences organizational performance when the level of significance is five percent. Table 3 shows details of our ANOVA test.

Table 3

The summary of ANOVA test for the first regression model

\begin{tabular}{llllllll}
\hline Model & Sum of Square & Degree of freedom & Sum of squares & F & R & $\mathrm{R}^{2}$ & Sig. \\
\hline ESS & 43.209 & 4 & 10.802 & 39.792 & 0.610 & 0.373 & 0.000 \\
RSS & 72.753 & 268 & 0.271 & & & & \\
\hline TSS & 115.961 & 272 & & & & & \\
\hline
\end{tabular}

As we can observe from the results of ANOVA test, $F$ value is meaningful when the level of significance is one percent and we can conclude that there is a linear relationship between independent variables.

The second regression model is as follows,

$$
O L=\beta_{0}+\beta_{1} H C+\beta_{2} S C+\beta_{3} R C+\varepsilon_{i},
$$

where $O L$ represents organizational learning, $H C$ is human capital, $S C$ is structural capital, $R C$ is the relational capital. In addition, $\beta_{i}, i=0, \cdots, 3$ are the coefficients of the regression analysis and $\varepsilon_{i}$ is the residual of the regression estimation. Table 4 shows details of implementation of ordinary least square technique.

\section{Table 4}

The results of regression analysis for the second regression model

\begin{tabular}{lllll}
\hline \multicolumn{5}{c}{ Regression estimation } \\
\hline Variable & Non-standard & Standard & t-student & P-value \\
\hline Constant & 1.893 & & 5.651 & 0.000 \\
Human capital & 0.059 & 0.063 & 1.224 & 0.222 \\
Structural capital & 0.010 & 0.015 & 0.287 & 0.774 \\
Relational capital & 0.503 & 0.531 & 10.278 & 0.000 \\
\hline
\end{tabular}

As we can observe from the results of Table 4, neither human capital nor structural capital maintains any meaningful impact on organizational learning when the level of significance is one or even ten percent. However, relational capital maintains a meaningful impact on organizational learning when the level of significance is one percent and we can expect that as the relational capital increases by one percent, we could expect an increase of 0.503 on organizational learning. Table 5 shows details of our ANOVA test.

\section{Table 5}

The summary of ANOVA test for the second regression model

\begin{tabular}{llllllll}
\hline Model & Sum of Square & Degree of freedom & Sum of squares & F & R & $\mathrm{R}^{2}$ & Sig. \\
\hline ESS & 26.526 & 3 & 8.742 & 37.635 & 0.544 & 0.296 & 0.000 \\
RSS & 63.198 & 269 & 0.235 & & & & \\
\hline TSS & 89.724 & 272 & & & & & \\
\hline
\end{tabular}

As we can observe from the results of ANOVA test, F value is statistically meaningful when the level of significance is one percent and we can conclude that there is a linear relationship between independent variables. 
The last regression model is as follows,

$R C=\beta_{0}+\beta_{1} H C+\varepsilon_{i}$,

where $R C$ represents relational capital and $H C$ is human capital. In addition, $\beta_{i}, i=0,1$ are the coefficients of the regression analysis and $\varepsilon_{i}$ is the residual of the regression estimation. Table 6 shows details of implementation of ordinary least square technique.

\section{Table 6}

The results of regression analysis for the third regression model

\begin{tabular}{lllll}
\hline \multicolumn{5}{c}{ Regression estimation } \\
\hline Variable & Non-standard & Standard & t-student & P-value \\
\hline Constant & 3.068 & & 13.786 & 0.000 \\
Human capital & 0.132 & 0.133 & 2.217 & 0.000 \\
\hline
\end{tabular}

As we can observe from the results of Table 6, human capital has meaningful impact on relational capital when the level of significance is one percent. Table 7 shows details of our ANOVA test.

\section{Table 7}

The summary of ANOVA test

\begin{tabular}{llllllll}
\hline Model & Sum of Square & Degree of freedom & Sum of squares & F & R & R $^{2}$ & Sig. \\
\hline ESS & 1.778 & 1 & 1.778 & 4.917 & 0.018 & 0.133 & 0.027 \\
RSS & 97.976 & 271 & 0.362 & & & & \\
\hline TSS & 99.754 & 272 & & & & & \\
\hline
\end{tabular}

As we can observe from the results of ANOVA test, $F$ value is statistically meaningful when the level of significance is five percent and we can conclude that there is a linear relationship between independent variables. In summary, we can summarize the results of examining all hypotheses in Table 8 as follows,

\section{Table 8}

The summary of testing ten hypotheses

\begin{tabular}{llllll}
\hline & Hypotheses & $\beta$ & t-student & Result \\
\hline Human capital & $\rightarrow$ & Organizational performance & 0.159 & $3.046^{* *}$ & Confirmed \\
Structural capital & $\rightarrow$ & Organizational performance & 0.043 & 1.091 & Reject \\
Relational capital & $\rightarrow$ & Organizational performance & 0.516 & $8.308^{* *}$ & Confirmed \\
Learning capabilities & $\rightarrow$ & Organizational performance & 0.157 & $2.393^{*}$ & Confirmed \\
Human capital & $\rightarrow$ & Learning capability & 0.059 & 1.224 & Reject \\
Structural capital & $\rightarrow$ & Learning capability & 0.010 & 0.287 & Reject \\
Relational capital & $\rightarrow$ & Learning capability & 0.503 & $10.27^{* *}$ & Confirmed \\
Human capital & $\rightarrow$ & Structural capital & 0.088 & 1.09 & Reject \\
Relational capital & $\rightarrow$ & Structural capital & 0.031 & 0.386 & Reject \\
Human capital & $\rightarrow$ & Relational Capital & 0.132 & $2.217^{*}$ & Confirmed \\
\hline ** Significance level = one percent & & & & &
\end{tabular}

Based on the summary of the results given in Table 8, we can conclude that human capital, relational capital and learning capabilities have positive impact on organizational performance. In addition, relational capital positively impacts learning capability and human capital influences positively on relational capital. Organizational learning is a kind of process where the organization continuously 
puts exposed to criticism and to question existing systems and explains strategic position to applied various patterns and to reach sustainable competitive results. Having a competitive advantage depends on the advantages of each organization, but certainly, the organization's staff and their knowledge plays an important role in this pathway. In other words, learning is the primary source of competitive advantage. Learning in any organizational also could be converted to change and positive change.

\section{Conclusion}

In this paper, we have presented an empirical study to measure the impact of human, structural and relational capital on organizational learning. We have also studied the relationship between all independent variables. The study has been implemented for a real-world case study in Iran and the results have indicated that human capital, relational capital and learning capabilities have positive impact on organizational performance. In addition, relational capital positively impacts learning capability and human capital influences positively on relational capital.

\section{Acknowledgment}

The authors would like to thank the help and insights provided by anonymous referees on earlier version of this paper.

\section{References}

Ali, A.M., Qadus, A., Waseem, A., \& Zaman, K. (2012). Linking knowledge management practices and the organizational performance of Pakistan's telecommunication. Management Science Letters, 2(8), 2929-2938.

Bontis, N., Dragonetty, N.C., Jacobsen, K., \& Roos, G. (1999).The Knowledge Toolbox: A review of the tools available to measure and manage intangible resources. European Management Journal, 17(14), 391-402.

Bontis, N., Keow, W.C.C., \& Richardson, S. (2000). Intellectual capital and business performance in Malaysian industries. Journal of Intellectual Capital, 1(1), 85-100.

Bontis, N., \& Serenko, A. (2009). A causal model of human capital antecedents and consequents in the financial services industry. Journal of Intellectual Capital, 10(1), 53-69.

Brooking, A. (1996). Intellectual Capital: Core Assets for the Third Millennium Enterprise. International Thompson Business Press, London.

Cronbach, L. J. (1951). Coefficient alpha and the internal structure of tests. Psychometrika, 16(3), 297-334.

Hsu Y., \& Fang W. (2009). Intellectual capital and new product development performance: The mediating role of organizational learning capability. Technological Forecasting and Social Change, 76(5), 664-677.

Moullin, M. (2002). Delivering Excellence in Health and Social Care. Buckingham, Open University Press.

Riahi-Belkaoui, A. (2003).Intellectual capital and firm performance of US multinational firms. Journal of Intellectual Capital, 4 (2), 215-226.

Saeidipour, B., Akbari, P., Marati Fashi, M.A. (2012). Study the effect of emotional intelligence on organizational learning staff, Case study: Jihad Agriculture Organization of Isfahan. Management Science Letters, 2(7), 2501-2510.

Sonnier, B. M., Carson, D. C., \& Carson, P. P. (2007). Accounting for Intellectual Capital: The Relationship between Profitability and Disclosure. Journal of Applied Management and Entrepreneurship, 12 (2), 3-14. 
Stewart, T. A. (1997). Intellectual Capital: The New Wealth of Organizations. New York: Doubleday.

Veismoradi, A., Akbari, P., \& Rostami, R. (2012). A study on the effect of social capital on learning organization: A case study of Jihad Agriculture Organization of Kermanshah, Iran. Management Science Letters, 2(8), 2909-2916.

Valaski, J., Malucelli, A., \& Reinehr, S. (2012). Ontologies application in organizational learning: A literature review Review Article. Expert Systems with Applications, 39(8), 7555-7561.

Yu Yuan Hung, R., Yang, B., Ya-Hui Lien, B., McLean, G.N., \& Kuo, Y.M. (2010). Dynamic capability: Impact of process alignment and organizational learning culture on performance. Journal of World Business, 45(3), 285-294. 